\title{
Diversity of economic development in Portuguese-speaking countries
}

\author{
Mikhail Savelyev ${ }^{1}$, Elena Kutyashova $^{3}$, Andrey Savchenko ${ }^{1}$, Vladimir Koretsky ${ }^{2}$, and Yuri \\ Polyakov $^{3}$ \\ ${ }^{1}$ Mitra Association, Pushkinskaya Str. 241, 60, 426008 Izhevsk, Russia \\ ${ }^{2}$ M.T. Kalashnikov IzhSTU, Studencheskaya Str. 7, 426069 Izhevsk, Russia \\ ${ }^{3}$ Udmurt State University, Universitetskaya Str. 1, 426034 Izhevsk, Russia
}

\begin{abstract}
The rates of growth and stability of economic development of the countries of the Portuguese world in the years 1870-2018 are investigated. The comparison has been carried out for 15 economic cycles, which are grouped into following historical periods: monarchical, dictatorial and democratic. The developed method for researching economic development policies makes it possible to quantitatively assess the historical fate of territories in terms of growth and risk. The indicators of the standard deviation of the growth rates of real gross domestic product were used as an indicator of sustainability. The features of progressive, regressive, conservative and aggressive policies of economic development are described. It is shown that during the entire studied period, only Spain which is beyond the Portuguese-speaking word demonstrated similarity in development with Portugal. Brazil's development trend deviated from the metropolis after 130 years of independence and 60 years of obvious institutional differences. African colonies in their turn immediately began to demonstrate a drastically different development policy. This proves that culture has a more significant and long-term impact on economic development than state and social institutions. The results obtained show that the Portuguese world has not formed a separate civilization with special and peculiar traits to be united with the common historical fate.
\end{abstract}

\section{Introduction}

The work examines the development of the economy of Portugal, as well as countries that were part of the same State entity at different times or use the Portuguese language as a state language. From the metropolis, the former colonies borrowed the Portuguese language and the Catholic religion, but other cultural differences between them are significant.

The following important studies of the economic development of Portuguese-speaking countries can be mentioned. The work by V.L. Vernikov is devoted to the results of 40 years of development of Portugal after the revolution [1. c.7]. The features of the Portuguese economy associated with the emergence of an effect comparable to the socalled Dutch disease were considered in the work of Andrade J.S., Duarte A.P. [2]. Moore $\mathrm{Ph}$. analyzes Portugal's policy on overcoming the economic crisis [3]. The study of economic relations between Portugal and Brazil is devoted to the study of Martynova E.I. [4]. In the work of Averina T.N., Levkina N.N. the presence of powerful cycles of the 
economic dynamics of Portugal known as the Kondratyev waves was established [5]. Rozinskaya N.A. runs a comparative analysis of the development of Portugal and Holland, noting the similar initial conditions of the two countries including territory, population, geographic location and differences that led to different trajectories of social and economic development [6]. In the work of Medyshevsky N.A. results of the study of the economic development of Brazil are presented [7].

This study focuses on the hypothesis about the presence or absence of similarity in the economic development of Portuguese-speaking countries whether the cultural and linguistic proximity of these countries affects the trends of economic development and how quickly postcolonial institutions lose their implication in the former colonies. As an alternative hypothesis, the similarity of the development of Portugal with other language, but the closest to it in culture and geography, Spain is considered. In this case, the similarity of historical destinies can depend not on linguistic and institutional convergence, but on deeper mental and geographical factors.

\section{Materials and Methods}

The subject of this research is the economy of Portugal and Portuguese-speaking countries in the context of models of economic development and their results in the historical retrospective of 1870-2018.

The research methodology is based on the use for assessing economic development, in addition to the usual indicators of economic growth (growth rates of the real gross domestic product) and some extra indicators related to stability (risks) of this development. They are the standard deviations (hereinafter SD) of the growth rates of the real gross domestic product (hereinafter GDP). The period of risk assessment is determined by the economic cycle from the first year of the beginning (or acceleration) of economic growth to the last year of recession (or slowdown in growth) of the metropolis. This approach makes it possible to assess the quality of the economic decisions made and their implementation in different economic models of one particular culture, in this case the Portuguese-speaking one.

Within the framework of this approach, it is accepted to consider changes in the economy as progressive when the subsequent period, in comparison with the previous one, has a higher growth rate of macroeconomic indicators and a lower risk indicator (hereinafter RI). On the contrary, a decrease in growth and an increase in risks are indicators of the regressive economic development. In the case of a mutual decline in growth rates and risks, economic development is conservative, and in the case of growth, it is aggressive. This approach is theoretically substantiated in earlier studies by the authors, which shows the relationship between culture and institutional models [8-11]. The data sources were Angus Maddison Historical Statistics [12,13] and World Bank [14].

\section{Results and Discussion}

The results of the analysis of the growth and stability of the GDP of the Portuguesespeaking countries are presented in Fig. 1. The period of economic development of Portugal in 1870-1918, which can be conditionally called 'monarchic', is characterized by stagnation of the economy, when the economic activity was focused on trade and commodity in the colonies. The period 1919-1975 (the period of 'dictatorship') is characterized by the highest growth rates, but also lower stability. Economic growth during this period facilitated an economic integration with the advanced economies of Western Europe. The period 19762018 (the 'democratic' period) is characterized by lower growth rates, but at the same time an increase in the sustainability of economic development. This was an effect produced by 
the country's accession to the European Union, which contributed to stable economic growth and development, mainly due to the expansion of trade ties and the inflow of funds allocated by the EU.

The most successful development policies in Portugal and Spain were brought in life in 1959-1969, in Brazil in the next economic cycle. In African Portuguese-speaking countries, except for Guinea-Bissau, the peak of development fell on other postcolonial periods. In general, the transition from the monarchical period to the dictatorship in Portugal is characterized by aggressive development, and the transition to democracy - conservative. This completely correlates with the historical fate of Spain. Brazil, on the other hand, during the transition of Portugal from a monarchic to a dictatorial period, demonstrated a progressive policy, and during the transition to a democratic one, a conservative one.

If we talk about the African colonies, then for Angola and Mozambique the transition to independence was progressive, for Cape Verde and Equatorial Guinea it is characterized by aggressive development, and for Guinea-Bissau - regression. This does not in any way coincide with the conservative transition of Portugal during the same period.

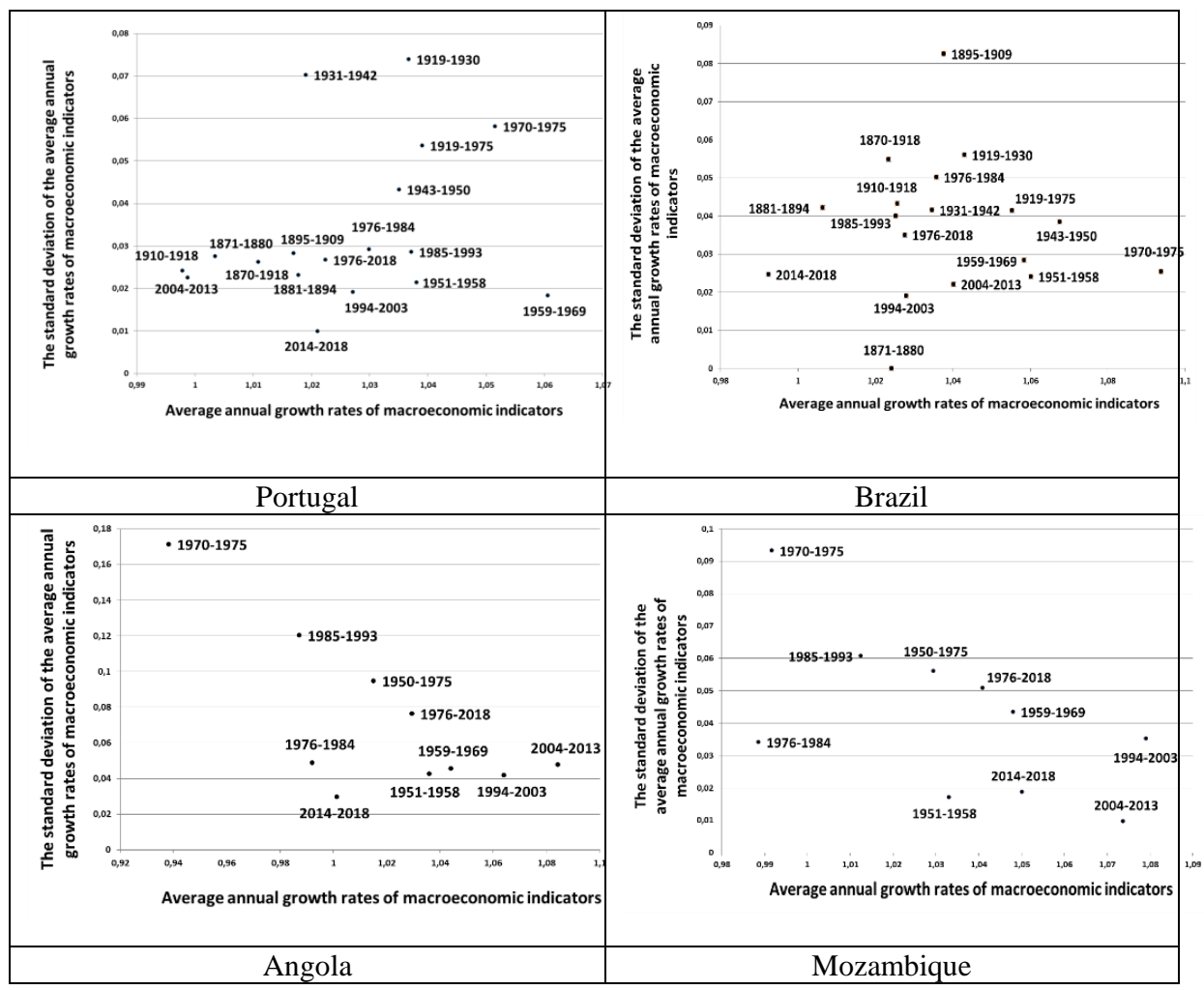




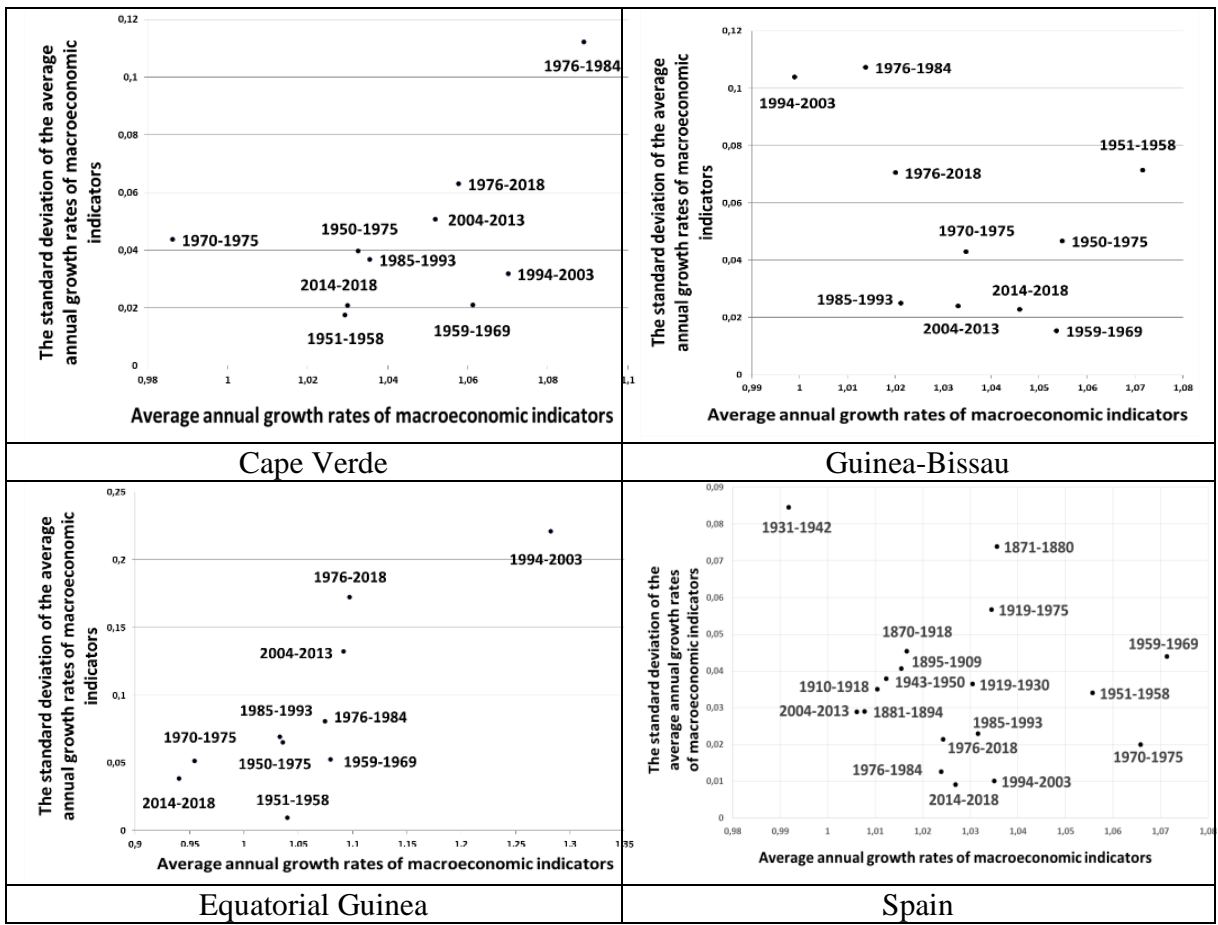

Fig. 1. Economic development of Portuguese-speaking countries

Table 1. Economic Development of Portuguese Speaking Countries

\begin{tabular}{|c|c|c|c|c|c|c|c|}
\hline $\begin{array}{c}\text { Country } \backslash \\
\text { period }\end{array}$ & $\begin{array}{c}1881- \\
1894 \\
\end{array}$ & $\begin{array}{c}1895- \\
1909 \\
\end{array}$ & $\begin{array}{c}1910- \\
1918 \\
\end{array}$ & $\begin{array}{c}1919- \\
1930 \\
\end{array}$ & 1931-1942 & $\begin{array}{c}1943- \\
1950 \\
\end{array}$ & $\begin{array}{l}1951- \\
1958 \\
\end{array}$ \\
\hline Portugal & $\begin{array}{c}\text { Progressiv } \\
\text { e }\end{array}$ & $\begin{array}{l}\text { Regressi } \\
\text { ve }\end{array}$ & $\begin{array}{c}\text { Conservat } \\
\text { ive }\end{array}$ & $\begin{array}{l}\text { Aggress } \\
\text { ive }\end{array}$ & $\begin{array}{c}\text { Conservati } \\
\text { ve }\end{array}$ & $\begin{array}{c}\text { Progressiv } \\
\text { e }\end{array}$ & $\begin{array}{l}\text { Progressi } \\
\text { ve }\end{array}$ \\
\hline Brazil & $\begin{array}{c}\text { Regressiv } \\
\text { e }\end{array}$ & $\begin{array}{l}\text { Aggress } \\
\text { ive }\end{array}$ & $\begin{array}{c}\text { Conservat } \\
\text { ive }\end{array}$ & $\begin{array}{c}\text { Aggress } \\
\text { ive }\end{array}$ & $\begin{array}{c}\text { Conservati } \\
\text { ve }\end{array}$ & $\begin{array}{c}\text { Progressiv } \\
\text { e }\end{array}$ & $\begin{array}{l}\text { Conservat } \\
\text { ive }\end{array}$ \\
\hline Spain & $\begin{array}{c}\text { Conservat } \\
\text { ive }\end{array}$ & $\begin{array}{l}\text { Aggress } \\
\text { ive }\end{array}$ & $\begin{array}{l}\text { Conservat } \\
\text { ive }\end{array}$ & $\begin{array}{c}\text { Aggress } \\
\text { ive }\end{array}$ & $\begin{array}{c}\text { Regressiv } \\
\text { e }\end{array}$ & $\begin{array}{c}\text { Progressiv } \\
\text { e }\end{array}$ & $\begin{array}{c}\text { Progressi } \\
\text { ve }\end{array}$ \\
\hline
\end{tabular}

\begin{tabular}{|l|c|c|c|c|c|c|}
\hline $\begin{array}{c}\text { Country } \\
\text { period }\end{array}$ & $1959-1969$ & $1970-1975$ & $1976-1984$ & $1985-1993$ & $\begin{array}{c}1994- \\
2003\end{array}$ & $\begin{array}{c}2004- \\
2013\end{array}$ \\
\hline Portugal & Progressive & Regressive & Conservative & Progressive & $\begin{array}{c}\text { Conservat } \\
\text { ive }\end{array}$ & $\begin{array}{c}\text { Regressi } \\
\text { ve }\end{array}$ \\
\hline Brazil & Regressive & Progressive & Regressive & Conservative & $\begin{array}{c}\text { Progressiv } \\
\text { e }\end{array}$ & $\begin{array}{c}\text { Aggressi } \\
\text { ve }\end{array}$ \\
\hline Angola & Aggressive & Regressive & Progressive & Regressive & $\begin{array}{c}\text { Progressiv } \\
\text { e }\end{array}$ & $\begin{array}{c}\text { Aggressi } \\
\text { ve }\end{array}$ \\
\hline Mozambique & Aggressive & Regressive & Conservative & Aggressive & $\begin{array}{c}\text { Progressiv } \\
\text { e }\end{array}$ & $\begin{array}{c}\text { Conserv } \\
\text { ative }\end{array}$ \\
\hline Cape Verde & Aggressive & Regressive & Aggressive & Conservative & $\begin{array}{c}\text { Progressiv } \\
\text { e }\end{array}$ & $\begin{array}{c}\text { Regressi } \\
\text { ve }\end{array}$ \\
\hline $\begin{array}{l}\text { Guinea- } \\
\text { Bissau }\end{array}$ & Conservative & Regressive & Regressive & Progressive & $\begin{array}{c}\text { Regressiv } \\
\text { e }\end{array}$ & $\begin{array}{c}\text { Progress } \\
\text { ive }\end{array}$ \\
\hline $\begin{array}{l}\text { Equatorial } \\
\text { Guinea }\end{array}$ & Aggressive & Conservative & Aggressive & Conservative & $\begin{array}{c}\text { Aggressiv } \\
\text { e }\end{array}$ & $\begin{array}{c}\text { Conserv } \\
\text { ative }\end{array}$ \\
\hline Spain & Aggressive & Conservative & Conservative & Aggressive & $\begin{array}{c}\text { Progressiv } \\
\text { e }\end{array}$ & $\begin{array}{c}\text { Regressi } \\
\text { ve }\end{array}$ \\
\hline
\end{tabular}


Table 2. Index of coincidence of development policies of Portugal with Portuguese-speaking countries and Spain

\begin{tabular}{|l|c|c|c|c|}
\hline \multicolumn{1}{|c|}{ Country } & $\begin{array}{c}\text { Total number of } \\
\text { studied periods }\end{array}$ & $\begin{array}{c}\text { Number of } \\
\text { development } \\
\text { policies } \\
\text { coincidences }\end{array}$ & $\begin{array}{c}\text { Number of } \\
\text { opposite } \\
\text { development } \\
\text { policies Index of } \\
\text { coincidence of } \\
\text { development } \\
\text { policies }\end{array}$ & $\begin{array}{c}\text { Development } \\
\text { Policy } \\
\text { Coincidence Index }\end{array}$ \\
\hline Brazil & 13 & 4 & 3 & $(4-3) / 13=7,7 \%$ \\
\hline Angola & 6 & 1 & 1 & $(1-1) / 6=0$ \\
\hline Mozambique & 6 & 2 & 0 & $(2-0) / 6=33 \%$ \\
\hline Cape Verde & 6 & 2 & 1 & $(2-1) / 6=17 \%$ \\
\hline Guinea-Bissau & 6 & 2 & 0 & $(2-0) / 6=33 \%$ \\
\hline $\begin{array}{l}\text { Equatorial } \\
\text { Guinea }\end{array}$ & 6 & 0 & 2 & $(0-2) / 6=-33 \%$ \\
\hline Spain & 13 & 6 & 0 & $6 / 13=46 \%$ \\
\hline
\end{tabular}

The assessment of the development policy during the periods of individual economic cycles in the studied countries is presented in Table. 1. Results of the assessment of the coincidences of policies and opposite policies in these periods is seen in Table 2. It should be noted that convergence of the policies of Portugal and Brazil are observed in the first half of the 20th century, while in African countries the most of the convergence of policies with Portugal are observed in the colonial period (50\% for the Portuguese colonies). With Spain, the convergence of policies is observed in all periods, and opposite development trends are not revealed at all.

\section{Conclusions}

As a result of the research, we can draw the following conclusions. Brazil is the country most culturally and institutionally close to Portugal. It retained the trend of development of the metropolis until the middle of the 20th century: about 130 years after gaining independence and 60 years after the break with institutional succession with the metropolis. The African colonies of Portugal immediately after gaining independence turned to different development trends. These results indicate the importance of their cultural differences with the metropolis for prognosis to be made. Despite the fact that Portugal and Spain have not been part of the same state since 1640, the cultural ties between them are such that over the past 150 years, there has been a similarity in economic development between them.

It is safe to say that there is no similarity in economic development among the Portuguese-speaking countries, i.e., they have no signs of a common historical fate and consequently there is no reason to assume existence of Portuguese civilization. Portugal and Spain consistently show similarities in economic development, i.e., these countries have a common historical destiny and are part of the same civilization.

\section{Acknowledgements}

The reported study was funded by RFBR, project number 20-010-00869. 


\section{References}

1. Portugal: 40 Years after the Revolution, What is Next? Ed. by V.L.Vernikov, Reports of the IE RAS, 305 (2014)

2. J.S. Andrade, A.P. Duarte, RUDN Journal of Economics, S5, 214 (2013)

3. Ph. Moore, Euromoney, 43(518), 100 (2012)

4. E. I. Martynova, Current problems of Europe, 3 (2004)

5. T.N. Averina, N.N. Levkina, Bulletin of TulSU, Economic and legal sciences, 4-1 (2015)

6. N.A. Rozinskaya, Journal of Institutional Studies, 9(1), 39 (2017)

7. Nikolay A. Medyshevsky, International Organisations Research Journal, 4, 33 (2012)

8. M. Yu. Savelyev, Multicultural institutionalism: General economic theory of civilizations. The political economy of traditionalism. Network Society Project, 488 (2015)

9. M.Yu. Savelyev, Bulletin of the Udmurt University, Series "Economics and Law", 7, 76 (2015)

10. M.Yu. Savelyev, Bulletin of the Udmurt University, Series "Economics and Law", 7, 135 (2015)

11. Mikhail Savelyev, Natalia Pushina, Andrey Savchenko, E3S Web Conf., 208, 03052 (2020)

12. Angus Maddison, Historical Statistics, http://www.ggdc.net

13. J. Bolt, J.L. van Zanden, Economic History Review, 67(3), 627 (2014)

14. World Bank, "World Development Indicators", https://databank.worldbank.org/ 